\title{
Effect of orally administered beclomethasone dipropionate on calcium absorption from the gut in normal subjects
}

\author{
Brian J Smith, Patrick J Phillips, Peter R Pannall, Heather J Cain, William J H Leckie
}

\begin{abstract}
Background-There is evidence that patients with chronic obstructive airways disease and asthma who take inhaled steroids have a low bone density. As most of a drug given from a metered dose inhaler is actually swallowed, the possibility that swallowed beclomethasone dipropionate acts topically in the gut to impair calcium absorption was investigated. Such an effect, if sustained, may be a causative factor of long term bone loss.

Methods-A two week randomised, double blind, placebo controlled, crossover trial was performed in 12 normal volunteers. Subjects were randomly allocated to swallow beclomethasone dipropionate capsules ( $500 \mu \mathrm{g}$ twice a day) or placebo for one week. The alternate capsule was given throughout the second week. At the end of each week, calcium absorption was assessed by a strontium absorption test. Serum parathyroid hormone, plasma calcium, and plasma phosphate concentrations were determined on the last two days of each week. Twenty four hour urinary calcium, hydroxyproline, and cortisol concentrations were measured for four successive days in each week.
\end{abstract}

Results-All subjects completed the study. There was a $12 \%$ reduction in strontium absorption during the beclomethasone dipropionate ingestion week. There was also a $23 \%$ reduction in 24 hour urinary cortisol excretion during the same week.

Conclusions-Calcium absorption (measured by a strontium absorption test) was reduced by oral administration of beclomethasone dipropionate for one week. Decreased calcium absorption due to swallowed corticosteroid may contribute to side effects of inhaled steroids and further long term studies are needed.

(Thorax 1993;48:890-893)

Patients with asthma and chronic obstructive airways disease are a group at special risk of osteoporosis as shown by several studies reporting subnormal bone density or exces- sive fractures in such patients. ${ }^{1-9}$ Many of these studies have examined selected subject groups who were dependent on oral corticosteroids. Some included subgroups, however, who had received little or no oral corticosteroids, but who also had subnormal bone densities. ${ }^{23}$ Thus other causative factors need to be considered, such as inhaled corticosteroids. $^{3}$

About $90 \%$ of a metered dose of beclomethasone dipropionate given by inhalation is deposited in the mouth and oropharynx, and then swallowed, and less than $10 \%$ reaches the lungs. ${ }^{10}$ First pass metabolism in the liver and gut should attenuate any systemic effect of swallowed beclomethasone dipropionate. ${ }^{11-13}$ Most studies of systemic effects of inhaled beclomethasone dipropionate in adults found little or no effect below $1000 \mu \mathrm{g} /$ day. ${ }^{14}$ Hence, exclusively swallowed beclomethasone dipropionate may have a higher systemic threshold effect than the inhaled drug. A possible topical effect of the swallowed drug on the intestinal mucosa has not, however, been assessed to our knowledge.

Patients receiving oral corticosteroids may be predisposed to osteoporosis in various ways but especially by impaired calcium absorption in the gut. ${ }^{15-17}$ Glucocorticoids are known to influence the transport of calcium by an effect on calcium channels, ${ }^{13}$ and to affect intestinal calcium absorption by various mechanisms. ${ }^{18}$ Thus it is possible that swallowed beclomethasone dipropionate, and especially its potent, stable metabolite beclomethasone-17-monopropionate, ${ }^{19}$ could directly reduce calcium absorption in the small intestine. A topical gut effect of the swallowed fraction or a systemic effect could further reduce calcium absorption. We studied this possibility in subjects swallowing beclomethasone dipropionate for one week. Subjects swallowed beclomethasone dipropionate to avoid inter and intra subject variation in inhaler technique. We chose a dose of $1000 \mu \mathrm{g} /$ day as this approximates to the oral dose of the drug in patients taking high dose inhaled steroids. ${ }^{10}$

\section{Methods}

We studied 12 normal volunteers, who were hospital staff aged 24 to 60 years (six men; table 1). Subjects were paired roughly for age 
Table 1 Particulars of subjects

\begin{tabular}{|c|c|c|}
\hline \multirow[b]{2}{*}{ Sex } & \multirow{2}{*}{$\frac{B D P(\text { week 1) }}{A g e}$} & \multirow{2}{*}{$\begin{array}{l}\text { BDP (week 2) } \\
\text { Age }\end{array}$} \\
\hline & & \\
\hline \multicolumn{3}{|c|}{ Men: } \\
\hline & 25 & 25 \\
\hline & 40 & 26 \\
\hline & 42 & 39 \\
\hline \multicolumn{3}{|c|}{ Women: } \\
\hline & 24 & 27 \\
\hline & 35 & 30 \\
\hline & 39 & 60 \\
\hline
\end{tabular}

BDP_beclomethasone dipropionate.

and sex and randomly allocated to swallow beclomethasone dipropionate capsules (500 $\mu \mathrm{g}$ twice a day) or placebo capsules for one week. The alternate capsule was given throughout the second week in a cross over design.

All capsules were made of fast dissolving gelatin. In vitro capsule dissolution time in a gastric acid bath was five minutes. Placebo capsules contained lactose powder and had an appearance and taste that neither subject nor experimenter could distinguish from the beclomethasone dipropionate capsules. Each subject's usual dietary calcium was assessed by a dietitian, and subjects were advised not to deviate from their usual calcium intake, commencing one week before the study period, and continuing throughout the study. Due to the matched study design, there could be no influence of intersubject dietary calcium variation on within subject changes in strontium absorption.

\section{ASSAYS}

Strontium absorption tests were performed on the morning of days 7 (last day of week 1) and 14 (last day of week 2). Such tests are a validated measure of calcium-45 absorption in humans and previously published methodology was used. ${ }^{20-22}$ Briefly, $2.5 \mathrm{mmol}$ of strontium chloride in $200 \mathrm{ml}$ distilled water was given with a standardised breakfast that contained only $1.2 \mathrm{mmol}$ elemental calcium. (Breakfast comprised two slices of white bread, $10 \mathrm{~g}$ honey, $10 \mathrm{~g}$ butter, $100 \mathrm{~g}$ tinned peaches, and $50 \mathrm{ml}$ peach juice.) Subjects had no dairy products with the preceding evening meal, and had no oral intake other

Table 2 Mean (SD) results of assays for all 12 subjects; beclomethasone propionate week compared with placebo week

\begin{tabular}{|c|c|c|c|}
\hline Study factor & $B D P$ week & P week & $p$ \\
\hline $\begin{array}{l}\text { Strontium test } \\
(\% \text { of dose in ECF) }\end{array}$ & $9 \cdot 7(2 \cdot 1)$ & $11 \cdot 0(2 \cdot 0)$ & $<0.01$ \\
\hline $\begin{array}{l}\text { Plasma calcium } \\
\quad(\mathrm{mmol} / \mathrm{l}) \\
\text { Plasma phosphate }\end{array}$ & $2.38(0.08)$ & $2 \cdot 38(0.07)$ & NS \\
\hline $\begin{array}{l}\text { (mmol/l) } \\
\text { Serum parathyroid hormone }\end{array}$ & $1 \cdot 16(0 \cdot 14)$ & $1 \cdot 10(0 \cdot 14)$ & NS \\
\hline $\begin{array}{l}\text { (pmol/l) } \\
\text { Urinary cortisol }\end{array}$ & $43.9(8.4)$ & $44 \cdot 3(7 \cdot 5)$ & NS \\
\hline $\begin{array}{l}\text { (nmol/day) } \\
\text { Urinary hydroxyproline }\end{array}$ & $147(45)$ & $191(40)$ & $<0.0005$ \\
\hline $\begin{array}{l}(\mu \mathrm{mol} / \mathrm{day}) \\
\text { Urinary calcium }\end{array}$ & $210(61)$ & $222(111)$ & NS \\
\hline (mmol/day) & $2 \cdot 79(0.66)$ & $3.00(0.92)$ & NS \\
\hline
\end{tabular}

BDP_beclomethasone dipropionate; P_placebo; ECF-extracellular fluid. than water from $8.00 \mathrm{pm}$ the previous evening until the breakfast. A morning snack was given two hours after breakfast and comprised two dry biscuits and $250 \mathrm{ml}$ orange or mango juice. Blood was taken for strontium assay four hours after breakfast. For the day 14 strontium absorption tests, baseline plasma strontium concentrations were subtracted from the four hour plasma strontium concentration to obtain the percentage of the ingested dose in the extracellular fluid for that day's test. This repeated test would not be affected by saturation of active gut absorption or of clearance mechanisms as a result of the initial week's test. ${ }^{20}$

Serial 24 hour collections of urine for measurement of calcium, hydroxyproline, and cortisol concentrations were taken throughout days 3 to 7 (week 1), and again during days 11 to 14 (week 2). Twenty four hour urinary cortisol assays were used as a measure of the systemic effect of the swallowed beclomethasone dipropionate. Serum parathyroid hormone, plasma calcium and plasma phosphate concentrations were determined on days 6 and 7 (week 1), and again on days 13 and 14 (week 2).

\section{ANALYTICAL TECHNIQUES}

Plasma strontium was assayed by atomic absorption spectrophotometry (coefficient of variation $(\mathrm{CV})=3.5 \%)$; serum parathyroid hormone by the mid-molecule radioimmunoassay of Incstar (CV $=16 \%)$; plasma calcium and phosphate by Technicon SMAC (CV $=1.6 \%$ and $2.6 \%$ respectively); urinary hydroxyproline by the spectrophotometric method of Bergman and Loxley ${ }^{23}(\mathrm{CV}=5 \%)$; urinary cortisol radioimmunoassay with an Amersham Amerlex kit $(\mathrm{CV}=8 \cdot 2 \%)$; and urinary calcium by absorption spectroscopy $(\mathrm{CV}=2 \cdot 1 \%)$.

The study was performed with approval of the institute's ethics committee. Statistical analysis was by a two tailed paired $t$ test with Systat $5 \cdot 2$ software.

\section{Results}

All 12 subjects finished the study, and all strontium tests were completed. Eighty seven collections of urine and 139 of 144 blood assays were completed. The few failed tests resulted from errors of subject compliance and were not biased to any particular subject group. Subjects did not have side effects during the study. Table 2 shows the results for all assays for all 12 subjects with the beclomethasone dipropionate week compared with the placebo week. Table 3 shows the results for the two separate subject groups of six (placebo to beclomethasone dipropionate and beclomethasone dipropionate to placebo). There was a lower strontium absorption in 11 of 12 subjects during the beclomethasone dipropionate week compared with the placebo week (mean reduction $12 \%$, $\mathrm{p}<0.01$; fig 1 ). There was also a lower mean 24 hour urinary cortisol concentration in 12 subjects during the beclomethasone 
Figure 1 Strontium absorption as \% of dose in extracellular fluid (ECF) four hours after breakfast at the end of each week for the 12 subjects (six placebo in first week, six beclomethasone dipropionate in first week).

Figure 2 Urinary cortisol concentrations $/ 24$ hours averaged over each week for the 12 subjects (six placebo in first week, six beclomethasone dipropionate in first week).
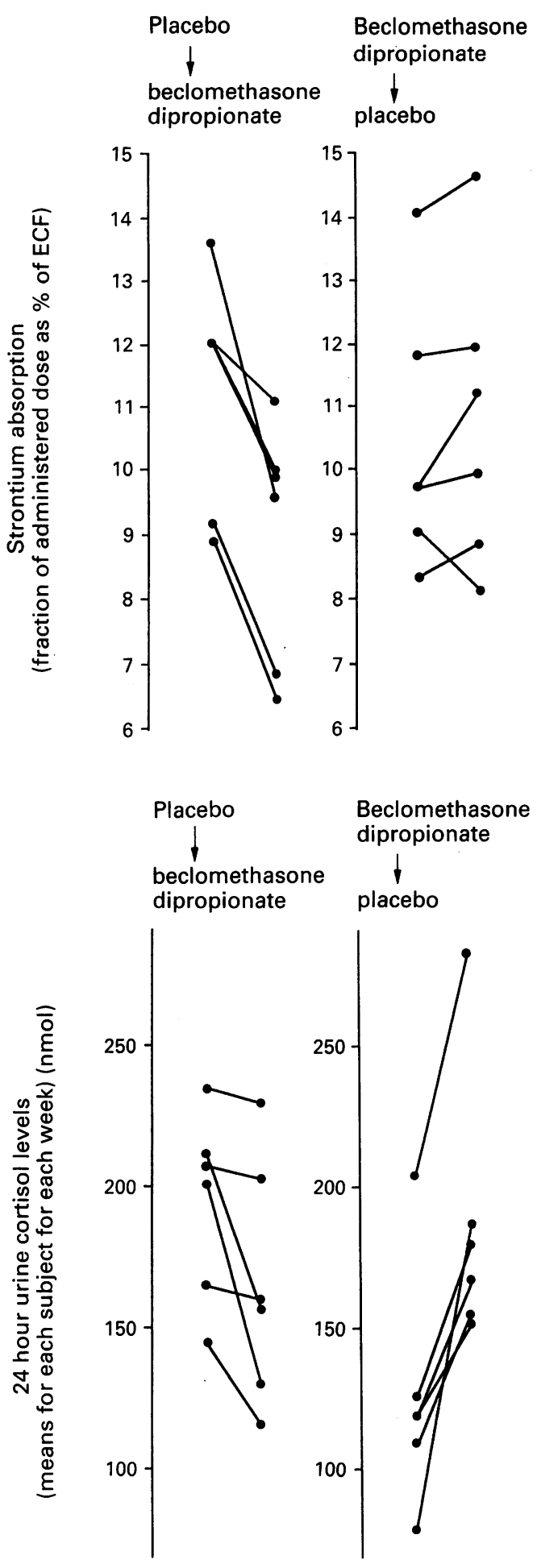

dipropionate compared with the placebo week (mean reduction 23\%, p < 0.0005; fig 2).

In the six subjects proceeding from placebo to beclomethasone dipropionate, there was a mean reduction of $20.3 \%$ in strontium absorption during the second week, with all six subjects having lower strontium absorp- $x$ tion when compared with values for the $\vec{F}$ placebo week $(p<0.005)$. In subjects pro- $\frac{?}{0}$ ceeding from beclomethasone dipropionate to placebo, there was a mean increase of $3.2 \% \overline{\frac{}{\omega}}$ for strontium absorption in the second $\widetilde{\Phi}$ (placebo) week, but this was not significant. No other assays showed a significant differ- ${ }^{\infty}$ ence between the beclomethasone dipropi- $\stackrel{0}{.}$ onate and placebo weeks, apart from an $\vec{\omega}$

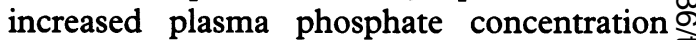
during the first week of beclomethasone $\overrightarrow{\vec{x}}$ dipropionate ingestion.

\section{Discussion}

Inhalation from a metered dose inhaler $\stackrel{\circ}{\circ}$ results in a much greater deposition of topical $\vec{c}$ corticosteroid within the intestine than in the $\frac{D}{8}$ lungs. ${ }^{10}$ Topical corticosteroids may have $\stackrel{\oplus}{\oplus}$ potent actions on mucosal surfaces. ${ }^{24}$ Within $\frac{3}{8}$ the intestinal lumen, beclomethasone dipro- $\frac{\Phi}{\square}$ pionate is hydrolysed to beclomethasone-17- $\overrightarrow{0}$ propionate, which has much greater glucocorticoid receptor affinity. ${ }^{19}$ Thus hydrolysis is an important activation step within the intestine, and increases the possibility of a topical effect of the swallowed drug on calcium absorption in the intestine.

The lower strontium absorption during the $\overrightarrow{\vec{O}}$ beclomethasone dipropionate week suggests 3 that intestinal strontium absorption is reduced by beclomethasone dipropionate, as there is no apparent reason for the drug to directly affect strontium clearance. The $20.3 \%$ reduction in strontium absorption in the placebo to beclomethasone dipropionate 3 . group was not mirrored by an increase of similar magnitude in the other cross over $₹$ group (fig 1). This may be due to an inade-응 quate washout period after beclomethasone dipropionate in the first week. Beclomethasone dipropionate is unaffected by gastric fluid in vitro, and is slowly metabolised to the more potent beclomethasone-17-monopropionate within the

Table 3 Mean (SD) results of assays for the two separate study groups

\begin{tabular}{|c|c|c|c|c|c|c|}
\hline \multirow[b]{2}{*}{ Study factor } & \multicolumn{3}{|l|}{$P$ to $B D P$ group } & \multicolumn{3}{|l|}{ BDP to P group } \\
\hline & $P$ & $B D P$ & $p$ & $B D P$ & $P$ & $p$ \\
\hline $\begin{array}{l}\text { Strontium test } \\
\text { (\% of dose in ECF) }\end{array}$ & $11 \cdot 3(1 \cdot 8)$ & $9.0(1.9)$ & $<0.005$ & $10 \cdot 4(2 \cdot 1)$ & $10 \cdot 7(2 \cdot 4)$ & NS \\
\hline $\begin{array}{l}\text { Plasma calcium } \\
((\mathrm{mmol} / \mathrm{l})\end{array}$ & $2.41(0.07)$ & $2.39(0.05)$ & NS & $2.37(0.10)$ & $2.36(0.07)$ & NS \\
\hline $\begin{array}{l}\text { Plasma phosphate } \\
(\mathrm{mmol} / \mathrm{l})\end{array}$ & $1 \cdot 13(0 \cdot 14)$ & $1 \cdot 13(0 \cdot 17)$ & NS & $1 \cdot 18(0 \cdot 10)$ & $1.07(0 \cdot 10)$ & $<0.05$ \\
\hline $\begin{array}{l}\text { Serum parathyroid } \\
\text { hormone }(\mathrm{pmol} / \mathrm{l})\end{array}$ & $40(41)$ & $41(3.9)$ & NS & 47 (11) & $49(8)$ & NS \\
\hline $\begin{array}{l}\text { Urinary cortisol } \\
\text { (nmol/day) }\end{array}$ & $194(33)$ & $166(43)$ & NS & $127(42)$ & $188(48)$ & $<0.005$ \\
\hline $\begin{array}{l}\text { Urinary hydroxyproline } \\
(\mu \mathrm{mol} / \text { day })\end{array}$ & $269(145)$ & $228(77)$ & NS & $193(39)$ & $173(30)$ & NS \\
\hline $\begin{array}{l}\text { Urinary calcium } \\
\text { (mmol/day) }\end{array}$ & $2.73(1.07)$ & $2.62(0.80)$ & NS & $2.96(0.48)$ & $3 \cdot 24(0 \cdot 73)$ & NS \\
\hline
\end{tabular}

BDP_beclomethasone dipropionate; $\mathrm{P}$-placebo; ECF-extracellular fluid. 
intestine. Beclomethasone-17-monopropionate is a stable product and only very slowly metabolised within the intestine. ${ }^{19}$ The parent compound is sparingly soluble and is poorly absorbed by the intestine. ${ }^{11} \mathrm{~A}$ combination of these factors could therefore account for a prolonged and potent glucocorticoid effect on intestinal mucosal calcium absorption, and thus may explain an inadequate washout in the beclomethasone dipropionate to placebo group.

The decrease in urinary free cortisol during beclomethasone dipropionate ingestion suggests that a systemic effect of the orally ingested drug occurred despite $(a)$ the weak systemic potency of beclomethasone dipropionate reported in previous studies, ${ }^{14}$ and (b) its expected high rate of first pass metabolism when swallowed. Hence, we cannot be sure to what degree the reduction in strontium absorption is topical rather than systemic. Whatever the mechanism, reduction of calcium absorption secondary to beclomethasone dipropionate may be clinically important to bone health, as long term suppression of calcium absorption is known to be associated with parathyroid mediated bone resorption, ${ }^{1725-29}$ and low calcium absorption is a major determinant of mineral density loss in vertebral bone. ${ }^{30}$ Our study assessed the effect of only one week of ingestion, however, and not the effects longer term. The effect of oral corticosteroids on calcium absorption and parathyroid concentrations is sustained, ${ }^{17} 2829$ and therefore a sustained effect remains possible with swallowed beclomethasone dipropionate; this requires further evaluation.

Our study was on normal volunteers but there is no known reason why a suppressive effect on calcium absorption would not also apply to patients with asthma or chronic obstructive airways disease; again further research is needed.

Inhaled corticosteroids affect various indices relevant to bones, ${ }^{31-34}$ but a reduction in calcium absorption secondary to treatment with beclomethasone dipropionate has not, to our knowledge, been reported previously.

More research is required to assess the possibility of chronic suppression of calcium absorption in patients rather than healthy volunteers. Effects on other bone indices, particularly bone density, also require further assessement.

1 Luengo $M$, Picado C, Del Rio L, Guanabens N, Montserrat JM, Setoain J. Vertebral fractures in steroid dependent asthma and involutional osteoporosis: a comparative study. Thorax 1991;46:803-6.

2 Hens C, Bohning W. Does COPD affect bone minera content? Pneumologie 1990;44:(suppl 1):204-5.

3 Reid DM, Nicoll J, Smith MA, Higgins B, Tothill P, Nuki G. Corticosteroids and bone mass in asthma comparisons with rheumatoid arthritis and polymyalgia rheumatica. $B M F$ 1986;293:1463-6.

4 Medici TC, Ruegsegger P. Does alternate-day cloprednol therapy prevent bone loss? A longitudinal double-blind controlled clinical study. Clin Pharmacol Ther 1990; 48:455-66.
5 Thomas TPL. The complications of systemic corticosteroid therapy in the elderly. A retrospective study. Gerontology 1984;30:60-5.

6 Adinoff AD, Hollister JR. Steroid induced fractures and bone loss in patients with asthma. $N$ Engl f Med 1983; 309:265-8.

7 Lewczuk J, Wrabec K, Piszko P, Jagas J. Osteoporosis caused by long-term steroid therapy of patients with chronic asthmatic bronchitis. Wiad Lek 1990;43:940-4.

8 Kwong FK, Sue MA, Klaustermeyer WB. Corticosteroid complications in respiratory disease. Ann Allergy 1987; 58:326-30.

9 Greenberger PA, Hendrix RW, Patterson R, Chmiel JS. Bone studies in patients on prolonged systemic corticosteroid therapy for asthma. Clin Allergy 1982;12:363-8.

10 Davies DS. Pharmacokinetics of inhaled substances. Postgrad Med f 1975;51(suppl 7):44-9.

11 Martin LE, Harrison C, Tanner RJN. Metabolism of beclomethasone dipropionate by animals and man. Postgrad Med f 1975;51(suppl 4):11-20.

12 Martin LE, Tanner RJN, Clark TJH, Cochrane GM Absorption and metabolism of orally administered beclomethasone dipropionate. Clin Pharmacol Ther 1974;15:267-75.

13 Morris MG. Mechanisms of action and therapeutic role of corticosteroids in asthma. F Allergy Clin Immunol 1985; 75:1-14.

14 Cochrane GM, ed. Inhaled beclomethasone dipropionate systemic effects reviewed. Aberystwyth: Castle Press, 1989.

15 Need AG. Corticosteroids and osteoporosis. Aust $N Z \mathcal{Z}$ Med 1987;17:267-72.

16 Kimberg DV, Baerg RD, Gershon E, Graudasius RT. Effect of cortisone treatment on active transport of calcium by small intestine. F Clin Invest 1971;50:1309-21.

17 Reid IR. Pathogenesis and treatment of steroid osteoporosis. Clin Endocrinol 1989;30:83-103.

18 Lukert BP, Raisz LG. Gluco-corticoid induced osteoporosis: pathogenesis and management. Ann Intern Med 1990;112:352-64

19 Wurthwein G, Rhodewald P. Activation of beclomethasone dipropionate by hydrolysis to beclomethasone-17monopropionate. Biopharm Drug Dispos 1990;11: 381-94.

20 Reid IR, Pybus J, Lim TMT, Hannon S, Ibbertson HK. The assessment of intestinal calcium absorption using stable strontium. Calcif Tissue Int 1986;38:303-5.

21 Milsom S, Ibbertson K, Hannan S, Shaw D, Pybus J. Simple test of intestinal calcium absorption measured by stable strontium. BMF 1987;295:231-4.

22 Reid IR, Gallagher DJA, Bosworth J. Prophylaxis against vitamin $\mathrm{D}$ deficiency in the elderly by regular sunlight exposure. Age Ageing 1986;15:35-40.

23 Bergman J, Loxley $\mathbf{R}$. The determination of hydroxyproline in urine hydralysates. Clin Chim Acta 1970;27: 347-9.

24 McEvoy GK, ed. Drug information. Maryland: American Society of Hospital Pharmacists, 1987:1428-9;1592-3.

25 Riggs BL, Melton LJ. Involutional osteoporosis. N Engl $\mathfrak{F}$ Med 1986;314:1676-86.

26 Avioli LV, Lindsay $R$. The female osteoporotic syndrome(s). In: Avioli LV, Krane SM, eds. Metabolic bone disease and clinically related disorders. Philadelphia: Saunders, 1990.

27 Birge SJ, Avioli LV. Pathophysiology of calcium and phosphate absorptive disorders. In: Avioli LV, Krane SM, eds. Metabolic bone disease and clinically related disorders. Philadelphia: Saunders, 1990.

28 Chuchalin AG, Suleimanov SS, Gasanov SG, Grigorev AI, Shmushkovich BI. Study of calcitonin and parathyroid hormone in patients with bronchial asthma with steroid-induced osteoporosis. Probl Endokrinol (Mosk) 1983;29:19-20.

29 Fucik RF, Kukresja SC, Hargis CK, Bowser EN, Henderson WJ, Williams GA. Effect of glucocorticoids on function of the parathyroid glands in man. 7 Clin Endocrinol Metab 1975;40:152-5.

30 Nordin BEC, Robertson AR, Seamark RF, Bridges A, Philcox JC, Need AG, et al. The relation between calcium absorption, serum dehydroepiandrostenedione and vertebral mineral density in postmenopausal women. $\mathcal{F}$ Clin Endocrinol Metab 1985;60:651-7.

31 Pouw EM, Prummel MF, Oosting H, Roos CM, Endert E. Beclomethasone inhalation decreases serum osteocalcin concentrations. BMF 1991;302:627-8.

32 Teelucksingh S, Padfield PL, Tibi L, Gough KJ, Holt PR. Inhaled corticosteroids, bone formation, and osteocalcin. Lancet 1991;338:60-1.

33 Ali NJ, Capewell S, Ward MJ. Bone turnover during high dose inhaled corticosteroid therapy. Thorax 1991;46: $160-4$.

34 Jennings BH, Andersson KE, Johansson SA. The effects of inhaled budesonide vs oral prednisolone on adrenal function and markers of bone turnover. Eur $\mathcal{f}$ Clin Pharmacol 1991;40:77-82. 